\author{
(online) $=$ ISSN $2285-3642$ \\ ISSN-L = $2285-3642$ \\ Journal of Economic Development, Environment and People \\ Volume 9, Issue 1, 2020 \\ URL: http://jedep.spiruharet.ro \\ e-mail: office jedep@spiruharet.ro
}

\title{
Indicators of Entrepreneurial Behavior and Attitudes for Entrepreneurs of Slovenia and Croatia, in 2018/2019
}

\author{
Milena Ilić ${ }^{1}$ Marko Ranković ${ }^{2}$, Lazar Janić ${ }^{3}$ and Branislav Mitić 4 回 \\ ${ }^{1}$ ITS- Information Technology School, Belgrade, SERBIA \\ ${ }^{2}$ Faculty of Information Technology and Engineering, Belgrade, SERBIA \\ ${ }^{3}$ College of Health Vocational Studies in Belgrade, Belgrade, SERBIA \\ ${ }^{4}$ ITS- Information Technology School, Belgrade, SERBIA
}

\begin{abstract}
Following the theoretical presentation of entrepreneurship, that is, the determinants that determine the success of entrepreneurial ventures extracted from various scientific studies and research, the paper defines through research the indicators of entrepreneurial behavior and attitudes using the Global Entrepreneurship Monitor 2018/2019 Global Report database.
\end{abstract}

Using the methods of comparison, induction and deduction, an analysis of indicators of Entrepreneurial Behavior and Attitudes for Slovenia and Croatia was conducted.

Keywords: entrepreneurship, Global Entrepreneurship Monitor, Entrepreneurial behavior

JEL Codes: M21, M38, L26

How to cite: Ilić, M Ranković, M..Janić L, Mitić, B. (2019). Indicators of Entrepreneurial Behaviour and Attitudes for Entrepreneurs of Slovenia and Croatia, in 2018/2019. Journal of Economic Development, Environment and People, 8(2). doi: https://doi.org/10.26458/iedep.v8i4.641, p6-16

\section{Introduction}

The data required for the research was collected from Global Entrepreneurship Monitor 2018/2019 Global Report based on more than 200,000 interviews a year. Data were compared on the basis of Country Profiles of Slovenia and Country Profiles of Croatia, Growth of Entrepreneurial Opportunities Slovenia Executive Summary Report (2017) and Growth of Entrepreneurial Opportunities Croatia (2017). Although it would be interesting to include Serbia in comparison, unfortunately there is no comparable data for Serbia since 2009. The paper analyzes Indicators of Entrepreneurial Behavior and Attitudes for Slovenia and Croatia for the year 2018, based on available research from Global Entrepreneurship Monitor, its Global Report for 2018/2019, but other relevant bases were used as secondary sources such as reports from the World Economic Forum,

+ Corresponding author. Tel.: + 381605522 581; E-mail address: milena.ilic@its.edu.rs 


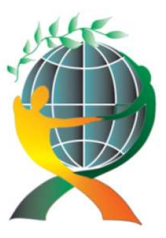

\author{
(online) = ISSN $2285-3642$ \\ ISSN-L = 2285 - 3642 \\ Journal of Economic Development, Environment and People \\ Volume 9, Issue 1, 2020 \\ URL: http://jedep.spiruharet.ro \\ e-mail: office jedep@spiruharet.ro
}

World Bank Ease of Doing Business, World Bank Starting a Business and National Statistical Bureaus of the Republic of Slovenia and the Republic of Croatia.

\title{
2. Literature Review
}

The importance of entrepreneurship for the development of the economy is of great importance. Even in the theory of economics, there is the attitude within the school of the economy that the state has no central role in the economy, but an entrepreneur. (Ilic, 2017)

Many international studies have investigated the determinants of entrepreneurship, and above all the characteristics of successful entrepreneurs and entrepreneurial ventures, trying to figure out the factors that influence the success of entrepreneurial ventures through the site characteristics of individuals (entrepreneur personality, educational level, origin), and then those factors related to the establishment of new enterprises (Armington, Acs, 2002), and related factors such as organizational, industrial and even geographical factor.

Some studies have looked at and recognized the impact of competitiveness such as creativity, thus innovation and technology, on the success of entrepreneurial ventures.

The Research was carried out by professors of Faculty of Economics in 2018 and it included the determinants that have an impact on international ventures of entrepreneurs in the early stages of business including the motivation of entrepreneurs, innovation, new technologies and demographics such as age and gender of respondents.

The results of the survey have proved that the entrepreneurs in the early stages of business, are motivated by financial performance and more focused on internationalization, while the necessity entrepreneurs, that is, those in the early stages of business were motivated on the path of independence. The survey has also indicated that the entrepreneurs who are in the early stages use radical innovations, new technologies are focusing on foreign consumers and foreign markets. Also, the survey has showed a correlation between gender, age and internationalization of entrepreneurs. (Leković et al., 2018)

Another study conducted by a professor of the Technical Faculty (Bor) tested the theoretical assumption of the main drivers of small and medium enterprises ( "creativity and innovation"), and measured their impact on the profitability of small and medium enterprises in the Republic of Serbia. Based on the conceptual model, it was conducted the survey on the sample of the 717 companies in the field of small and medium enterprises. The results showed that the creativity of entrepreneurs and knowledge transfer have a large impact on the innovation in organization, as well self-efficacy of entrepreneur and data collection can increase teamwork. Also, the results of this research have shown that innovation in organization and teamwork have a positive impact on profitability. (Jovanovic et al, 2018)

Regarding knowledge managements, authors finds that knowledge management rests on information systems. (Braicu, Bucea-Manea-Tonis, (2017).

The study of professors from Amity University Uttar Pradesh from India conducted in 2018 aimed to identify determinants that inspire entrepreneurs to succeed in entrepreneurial ventures (influence and vision), but also the style of leadership, motivation, restructuring, based on the case study. The results of the 


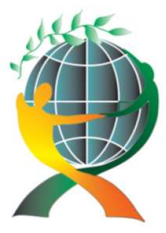

\author{
(online) = ISSN $2285-3642$ \\ ISSN-L = 2285 - 3642 \\ Journal of Economic Development, Environment and People \\ Volume 9, Issue 1, 2020 \\ URL: http://jedep.spiruharet.ro \\ e-mail: office jedep@spiruharet.ro
}

research have shown that the success of entrepreneurial ventures is not influenced only by self-motivation of entrepreneurs, but also his quality, knowledge of the opportunities from environments, developmental chances and courage to adapt to change. (Singh et al., 2018).

The study of women's agricultural entrepreneurship in the Republic of Serbia pointed out the correlation between economic development, gender equality and rural development of certain areas. The conclusion of the research is that women entrepreneurs strengthen gender equality which is an important indicator of economic development of modern society. When it comes to the Republic of Serbia, tradition and patriarchal way of upbringing may provide resistance. (Maksimovic et al, 2016)

In terms of gender and the formal and informal sector, research conducted by Webb's (2009) suggest that the informal sector is an important part of economic activity and that there is the influence of sex and gender on informality, because in certain regions such as the Middle East and North America, many companies owned by women are informal and located in their homes. (Alturki, Braswell, 2010

The attitude of the authors of scientific research work which gives an overview of the status and importance of further development of women's entrepreneurship (Drakulic, Budimčević, 2016) is that the number of women-owned businesses has increased, as well as the value of the same. Those who create economic policy must mitigate connecting of variables in the field of society and connect them with gendersensitive policies, but the activism of governmental sectors is also necessary with the aim of growth of female entrepreneurship and its development.

The most important entrepreneurs in information technology such as the founders of Apple, Alibaba, Dell, Google, Yahoo have common ground as individuals, and their brands as well. These are entrepreneurs who, thanks to the research and development, have created products and services for their basic market and reached monetization of ideas and technologies. (Mandal, Wong, 2017)

Based on EBRD Life in Transition Survey III data of 2016, a study (Korosteleva, Stepien-Baig, 2019) explored relationships between poverty alleviation, entrepreneurship and gender and found that entrepreneurial process contributes poverty reduction in transition economies. This study also show that women play important role in "shaping the entrepreneurship-poverty relationship."

\title{
3. Research Methodology
}

\subsection{Data collection}

Reliable data for research and examination are provided by Global Entrepreneurship Monitor. Global Entrepreneurship Monitor is a project that covers the assessment of entrepreneurial activities of the individuals' attitudes and attitudes towards entrepreneurial activities. The project was started in 1999 with the partnership of London Business School and Babson College. This is the largest study on entrepreneurship in the world. The aim of the program is to measure differences in the level of entrepreneurial activity of countries, and then to determine what factors lead to the achievement of a satisfactory level of entrepreneurship. An important goal is also to create economic policies in such a way that they increase the national level of entrepreneurial activities.

Unlike other subject new and small enterprises databases, GEM analyzes, at a quiet level, the behavior 


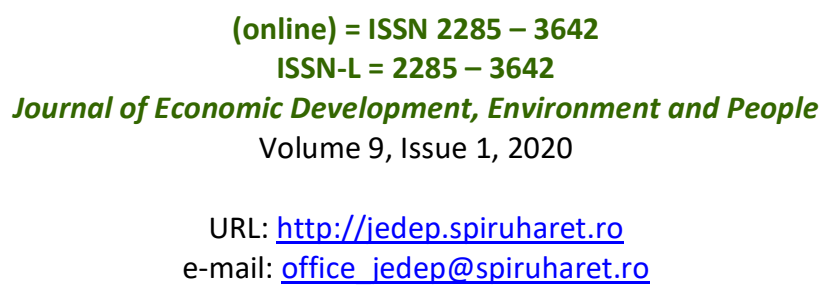

of individuals related to starting and managing business ventures. This approach provides a more detailed picture of entrepreneurial activities than official national databases.

Set of Variables:

\begin{tabular}{|l|}
\hline \multicolumn{1}{|c|}{ Variable(s) } \\
\hline Perceived opportunities \\
\hline Perceived capabilities \\
\hline Fear of failure \\
\hline Entrepreneurial intentions \\
\hline Improvement-Driven Opportunity/Necessity Motive \\
\hline TEA \\
\hline Established business ownership rate \\
\hline Entrepreneurial Employee Activity - EEA \\
\hline Female/Male TEA Ratio \\
\hline Female/Male Opportunity Ratio \\
\hline Job expectations (6+) \\
\hline Innovation \\
\hline Industry (\% in Business Services Sector) \\
\hline High status to entrepreneurs \\
\hline
\end{tabular}

Table 1. Set of Research Variables

Source: Authors based on: GEM Slovenia 2017 and GEM Croatia 2017 available at: https://www.gemconsortium.org/country-profile/107 (05.04.2019.)

\subsection{Republic of Slovenia}

Population of Slovenia in 2018 were 2.1 million (World Economic Forum). Slovenia has $5.0 \%$ annual \% change of GDP growth in 2017, and 34.6 thousand \$. According to World Bank Ease of Doing Business Rating for 2018 (World bank, 2019), Slovenia was at 75.61/100 with the rank: 40 of 190. When it comes to World Bank Starting a Business Rating for 2018 Slovenia was ranked 92.88/100; and at $38^{\text {th }}$ place among 190 countries. According to World Economic Forum Global Competitiveness Rank Slovenia is ranked 35 among 


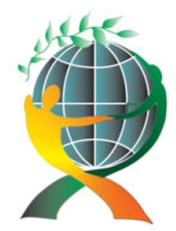

\author{
(online) $=$ ISSN $2285-3642$ \\ ISSN-L = 2285 - 3642 \\ Journal of Economic Development, Environment and People \\ Volume 9, Issue 1, 2020 \\ URL: http://jedep.spiruharet.ro \\ e-mail: office jedep@spiruharet.ro
}

140 countries. Slovenia has high rank at World Economic Forum Income Group Average.

Level-based entrepreneurs are at the same level but the TEA index in 2018, if we compare it to 2017, has decreased from $6.85 \%$ to $6.37 \%$. The reason for this problem was largely due to the fall emerging nascent entrepreneurs that fell from $4.02 \%$ in 2017 to $2.84 \%$. On the other hand, the share of new ones Entrepreneurs record growth from $2.96 \%$ to $3.64 \%$, due to a higher survival rate for entrepreneurs. The decline in the Slovenian TEA can be attributed, in part, to a strong economic growth of $4.2 \%$ in 2018 . This strong economic growth has increased demand for labor and the shortage of it in some regions. In this environment Individuals prefer less risky and well paid jobs unsafe business ventures. Certain parameters have increased such as perceived opportunities increased from $34.60 \%$ to $42.17 \%$, entrepreneurship as a good career choice $55.12 \%$ to $58.43 \%$, high state to successful entrepreneurs from $73.42 \%$ to $75.78 \%$, and the media the attention of entrepreneurship from $72.65 \%$ to $77.19 \%$.

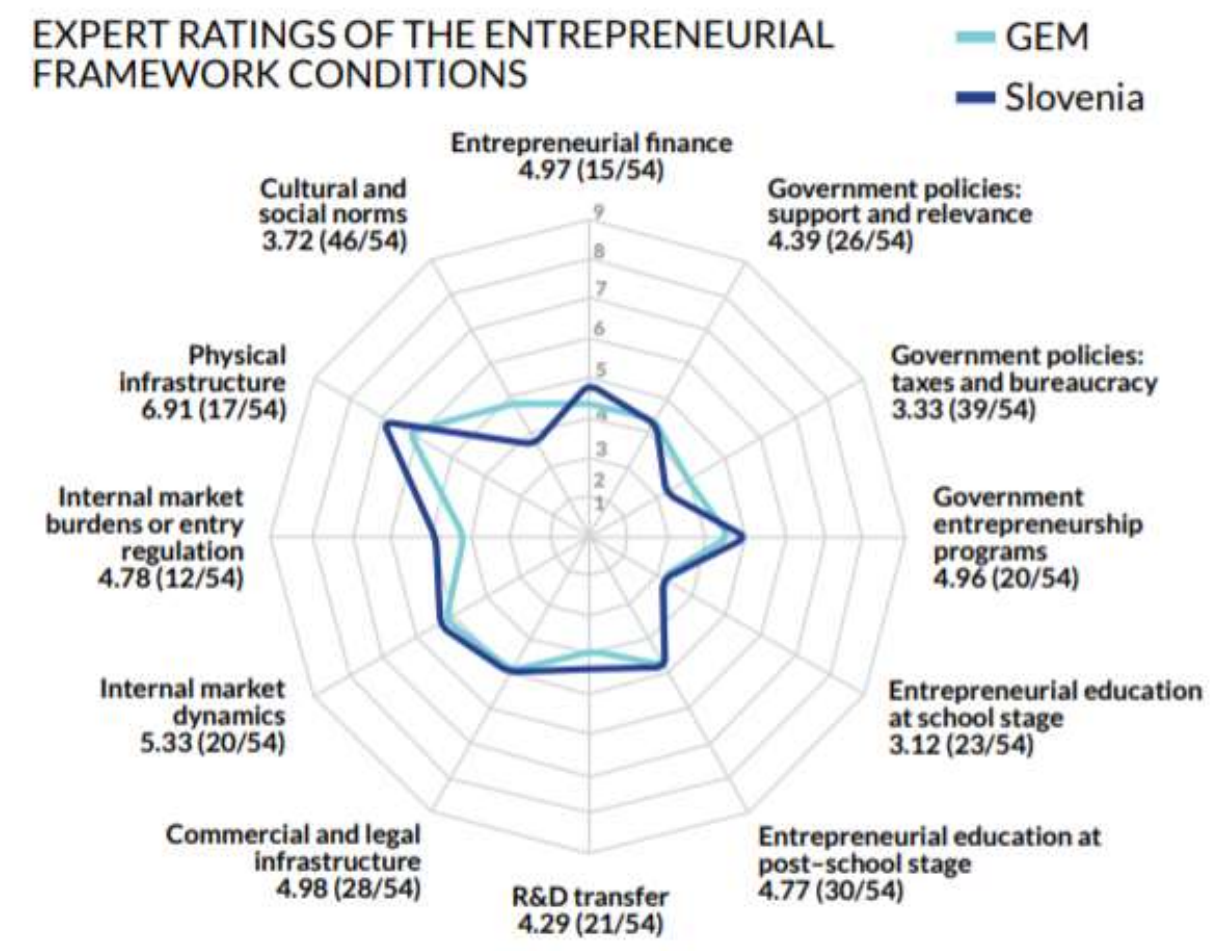

Figure 1. Expert rating of the entrepreneurial framework conditions for Slovenia ${ }^{1}$ Source: Global Entrepreneurship Monitor GEM 2018 / 2019 Global Report, available at: https://www.gemconsortium.org/report (06.04.2019.)

\footnotetext{
${ }^{1}$ EFCs scale: 1 = very inadequate insufficient status, 9 = very adequate sufficient status Rank out of 54 recorded in brackets (GEM 2018/2019)
} 


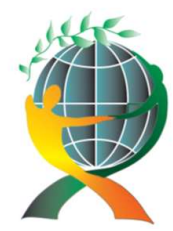

\author{
(online) $=$ ISSN $2285-3642$ \\ ISSN-L = 2285 - 3642 \\ Journal of Economic Development, Environment and People \\ Volume 9, Issue 1, 2020 \\ URL: http://jedep.spiruharet.ro \\ e-mail: office jedep@spiruharet.ro
}

Figure 1 shows Expert rating of the entrepreneurial framework conditions for Slovenia compared to GEM average.

\title{
3.3. Republic of Croatia
}

Population of Republic of Croatia in 2018 is 4.2 million. Annual GDP growth in 2017, \% change is $2.8 \%$. GGDP per Capita in 2017 international is 24.7 thousand \$. When it comes to World Bank Ease of Doing Business Rating for 2018 Croatia scored 71.40/100 and was Ranked 58/190. According to World Bank Starting a Business Rating for 2018 Croatia gained 82.62/100 and was ranked 123/190. According to World Economic Forum Global Competitiveness for 2018, Croatia was ranked 68/140. According to World Economic Forum Income Group Average for 2018, Croatia has High Income Average.

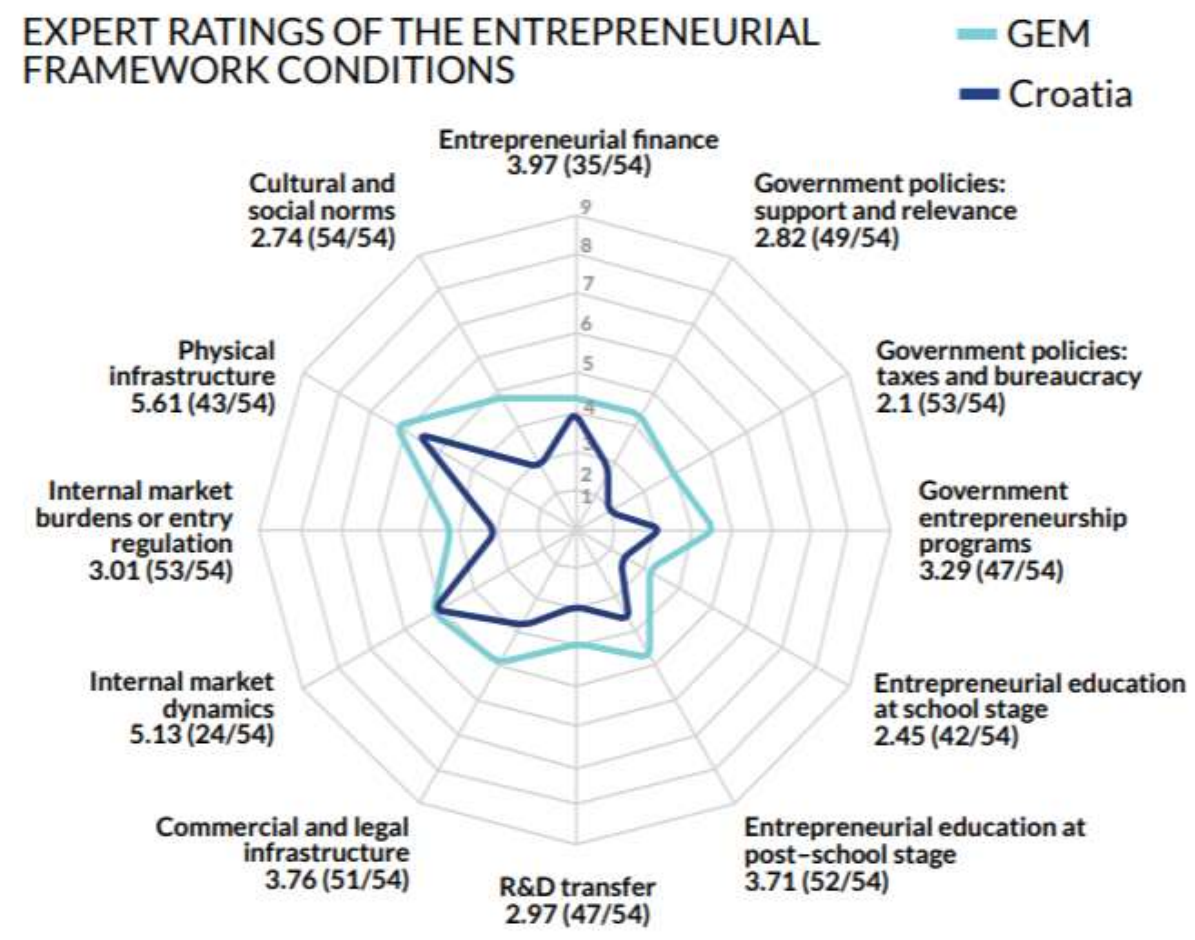

Figure 2. Expert rating of the entrepreneurial framework conditions for Croatia ${ }^{2}$ Source: Global Entrepreneurship Monitor GEM 2018 / 2019 Global Report, available at:

\footnotetext{
${ }^{2}$ EFCs scale: 1 = very inadequate insufficient status, 9 = very adequate sufficient status Rank out of 54 recorded in brackets (GEM 2018/2019)
} 


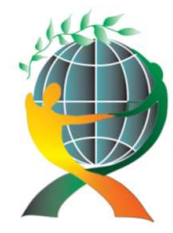

\author{
(online) $=$ ISSN $2285-3642$ \\ ISSN-L = $2285-3642$ \\ Journal of Economic Development, Environment and People \\ Volume 9, Issue 1, 2020 \\ URL: http://jedep.spiruharet.ro \\ e-mail: office jedep@spiruharet.ro
}

\title{
https://www.gemconsortium.org/report (06.04.2019)
}

For 2018 Croatia has shown its weaknesses when it comes to entrepreneurial capacity if we analyze relations among Croatian entrepreneurial activity and the quality of its national conditions. Bases od share of businesses that are advanced in technology level as well as based on share of businesses with new products, rate of businesses with growth potential is measured. Croatia in 2018 had low level of mentioned rate regarding Croatian's low education levels, R\&D transfer and government policies toward bureaucracy or taxation. (GEM, 2018/2019)

In the last few years, the GEM team in Croatia has made recommendations to simplify the regulatory framework and make recommendations to foster start-ups and existing businesses in order to create competitiveness. 2018. The Croatian Government has implemented measures to support cooperation between enterprises and research institutions in accordance with the recommendations of the GEM. New regulatory changes were prepared in the same year (GEM, 2018/2019)

\section{Entrepreneurial Behavior and Attitudes comparison Slovenia and Croatia}

GEM report analyze self-perceptions about Opportunities and Capabilities for Entrepreneurship among Adults ages between 18 and 64 in 49 Economies. Table 2 shows self-perceptions about entrepreneurship, values and rank for Slovenia and Croatia. Variables used are perceived opportunities, perceived capabilities, fear of failure and entrepreneurial intentions. When it comes to perceived opportunities Slovenia has better results (value) and has been ranked better than Croatia. When it comes to fear of failure, Slovenia shows higher value for this variable then Croatia. Croatia have better perceived capabilities then Slovenia and has been ranked higher. Also, regarding entrepreneurial intentions, Croatia has proven better results and positioned at higher rank.

\begin{tabular}{|l|l|l|l|l|}
\hline & $\begin{array}{l}\text { SLOVENIA } \\
\text { Value }\end{array}$ & $\begin{array}{l}\text { SLOVENIA } \\
\text { Rank/49 }\end{array}$ & $\begin{array}{l}\text { CROATIA } \\
\text { Value }\end{array}$ & $\begin{array}{l}\text { CROATIA } \\
\text { Rank/49 }\end{array}$ \\
\hline Perceived opportunities & 42.2 & 27 & 33.1 & 39 \\
\hline Perceived capabilities & 51.0 & $22 \mathrm{~T}$ & 52.3 & $18 \mathrm{~T}$ \\
\hline Fear of failure & 32.0 & 31 & 30.3 & $36 \mathrm{~T}$ \\
\hline Entrepreneurial intentions & 15.3 & $29 \mathrm{~T}$ & 18.6 & $26 \mathrm{~T}$ \\
\hline
\end{tabular}

Table 2. Self-Perceptions about entrepreneurship

Source: GEM Slovenia 2017 and GEM Croatia 2017 available at: https://www.gemconsortium.org/country-profile/107 (05.04.2019.)

Comparing TEA for 2018, 2017 and 2016, we found that Slovenia has lower value of this indicator then Croatia. Regarding established business ownership rate, Slovenia has bigger rate then Croatia. When it comes to EEA Entrepreneurial Employee activity Croatia has lower value then Slovenia. Total early-stage

\footnotetext{
${ }^{3}$ EFCs scale: 1 = very inadequate insufficient status, 9 = very adequate sufficient status Rank out of 54 recorded in brackets (GEM 2018/2019)
} 


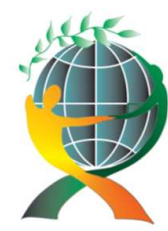

\author{
(online) $=$ ISSN $2285-3642$ \\ ISSN-L = $2285-3642$ \\ Journal of Economic Development, Environment and People \\ Volume 9, Issue 1, 2020 \\ URL: http://jedep.spiruharet.ro \\ e-mail: office jedep@spiruharet.ro
}

Entrepreneurial Activity for Slovenia and Croatia are shown in table 3.

\begin{tabular}{|c|c|c|c|c|}
\hline $\begin{array}{c}\text { Total early-stage } \\
\text { Entrepreneurial Activity (TEA) }\end{array}$ & $\begin{array}{c}\text { SLOVENIA } \\
\text { Value }\end{array}$ & $\begin{array}{c}\text { SLOVENIA } \\
\text { Rank }\end{array}$ & $\begin{array}{c}\text { CROATIA } \\
\text { Value }\end{array}$ & $\begin{array}{c}\text { CROATIA } \\
\text { Rank }\end{array}$ \\
\hline TEA 2018 & 6.4 & $39 T / 49$ & 9.6 & $30 T / 49$ \\
\hline TEA 2017 & 6.9 & $45 / 54$ & 8.9 & 34 T/54 \\
\hline TEA 2016 business & 8.0 & $48 / 65$ & 8.4 & $43 / 65$ \\
\hline $\begin{array}{c}\text { Established } \\
\text { ownership rate }\end{array}$ & 6.8 & $25 T / 49$ & 4.2 & 40 T/49 \\
\hline $\begin{array}{c}\text { Entrepreneurial Employee } \\
\text { Activity-EEA }\end{array}$ & 5.9 & $13 / 49$ & 5.3 & $15 / 49$ \\
\hline
\end{tabular}

Table 3. Activity

Source: Global Entrepreneurship Monitor GEM 2018 / 2019 Global Report, available at: https://www.gemconsortium.org/report (06.04.2019.)

Table 4. shows improvement driven opportunity or necessity as motivation. Slovenian entrepreneurs show to be on higher scale (rank) and show significantly higher level of value then Croatian,

\begin{tabular}{|c|l|l|l|l|}
\hline & $\begin{array}{l}\text { SLOVENIA } \\
\text { Value }\end{array}$ & $\begin{array}{l}\text { SLOVENIA } \\
\text { Rank/49 }\end{array}$ & $\begin{array}{l}\text { CROATIA } \\
\text { Value }\end{array}$ & $\begin{array}{l}\text { CROATIA } \\
\text { Rank/49 }\end{array}$ \\
\hline $\begin{array}{c}\text { Improvement-Driven } \\
\text { Opportunity/Necessity Motive }\end{array}$ & 20 & 26 & 1.4 & $35 T$ \\
\hline
\end{tabular}

Table 4. Motivational Index

Source: Global Entrepreneurship Monitor GEM 2018 / 2019 Global Report, available at: https://www.gemconsortium.org/report (06.04.2019.)

Table 5. shows Gender Equality in Slovenia and Croatia. Variables as Female/Male TEA Ratio (index) shows greater value and rank for Slovenia, and lower index and rank for Croatia.

\begin{tabular}{|c|l|l|l|l|}
\hline & $\begin{array}{l}\text { SLOVENIA } \\
\text { Value }\end{array}$ & $\begin{array}{l}\text { SLOVENIA } \\
\text { Rank/49 }\end{array}$ & $\begin{array}{l}\text { CROATIA } \\
\text { Value }\end{array}$ & $\begin{array}{l}\text { CROATIA } \\
\text { Rank/49 }\end{array}$ \\
\hline Female/Male TEA & 0.43 & 46 & 0.59 & $31 \mathrm{~T}$ \\
\hline $\begin{array}{c}\text { Female/Male Opportunity Driven } \\
\text { TEA }\end{array}$ & 0.86 & $36 \mathrm{~T}$ & 0.94 & $27 \mathrm{~T}$ \\
\hline
\end{tabular}

Table 5. Gender Equality

Source: Global Entrepreneurship Monitor GEM 2018 / 2019 Global Report, available at: https://www.gemconsortium.org/report (06.04.2019.)

Absorbed table 6 shows Entrepreneurship Impact as job expectations, innovation and type of industry and how those variables are measured. According to them, Croatia is better ranked within category of job expectations, while Slovenia is better as other 2 categories. 


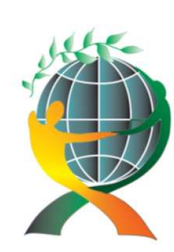

$$
\begin{gathered}
\text { (online) }=\text { ISSN 2285 - 3642 } \\
\text { ISSN-L }=2285-3642 \\
\text { Journal of Economic Development, Environment and People } \\
\text { Volume 9, Issue 1, } 2020
\end{gathered}
$$

URL: http://jedep.spiruharet.ro

e-mail: office jedep@spiruharet.ro

\begin{tabular}{|c|l|l|l|l|}
\hline & $\begin{array}{l}\text { SLOVENIA } \\
\text { Value }\end{array}$ & $\begin{array}{l}\text { SLOVENIA } \\
\text { Rank/49 }\end{array}$ & $\begin{array}{l}\text { CROATIA } \\
\text { Value }\end{array}$ & $\begin{array}{l}\text { CROATIA } \\
\text { Rank/49 }\end{array}$ \\
\hline Job expectations (6+) & 15.3 & $32 T$ & 26.5 & 15 \\
\hline Innovation & 25.5 & 26 & 24.6 & 28 \\
\hline $\begin{array}{c}\text { Industry (\% in Business } \\
\text { Services Sector) }\end{array}$ & 32.4 & $3 T$ & 28.9 & 7 \\
\hline
\end{tabular}

Table 6. Entrepreneurship Impact

Source: Global Entrepreneurship Monitor GEM 2018 / 2019 Global Report, available at: https://www.gemconsortium.org/report (06.04.2019.)

Table 7 shows Societal Value About Entrepreneurship and represents higher value of high status to entrepreneurs in Slovenia then in Croatia but for Croatian entrepreneur entrepreneurship is a good career choice, better then in Slovenia.

\begin{tabular}{|l|l|l|l|c|}
\hline & $\begin{array}{l}\text { SLOVENIA } \\
\text { Value }\end{array}$ & $\begin{array}{l}\text { SLOVENIA } \\
\text { Rank/49 }\end{array}$ & $\begin{array}{l}\text { CROATIA } \\
\text { Value }\end{array}$ & $\begin{array}{l}\text { CROATIA } \\
\text { Rank/47 }\end{array}$ \\
\hline High status to entrepreneurs & 75.8 & 16 & 43.0 & 47 \\
\hline Entrepreneurship a good career choice & 58.4 & 31 & 62.1 & 27 \\
\hline
\end{tabular}

Table 7. Societal Value About Entrepreneurship

Source: Global Entrepreneurship Monitor GEM 2018 / 2019 Global Report, available at: https://www.gemconsortium.org/report (06.04.2019.)

According to Global Entrepreneurship Monitor GEM 2018 / 2019 Global Report, Slovenia as well as other economics with small populations, entrepreneurs usually seek customers beyond their small internal markets.

When it comes to gender, railing on the same source, Slovenia has lack of gender equality, and in this state women start at less than half the rate of men. (GEM 2018/2019)

In Slovenia, about three/fourths of adults finds that there is positive media attention for entrepreneurship.

In Croatia entrepreneurship is most prevalent among ages 25-34, but ages 55-64 show rates less than a third that of overall TEA rates for Croatia, perhaps this has because of impact of employment, health, or retirement limit of this group's participation in entrepreneurship.

Less than half of those living in Croatia feels that successful entrepreneurs have high status.

\section{Connclusion}

The paper gives an overview of Indicators of Entrepreneurial Behavior and Attitudes for Entrepreneurs of Slovenia and Croatia, in 2018/2019. The Global Entrepreneurship Monitor 2018/2019 Global Report and other relevant statistical bases and reports were used as the source for the secondary research. 


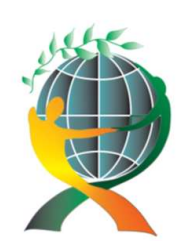

\author{
(online) $=$ ISSN $2285-3642$ \\ ISSN-L = $2285-3642$ \\ Journal of Economic Development, Environment and People \\ Volume 9, Issue 1, 2020 \\ URL: http://jedep.spiruharet.ro \\ e-mail: office jedep@spiruharet.ro
}

Based on the available data from the report, a comparison of the Entrepreneurial Behavior and Attitudes indicators for Slovenia and Croatia was made and conclusions drawn.

\title{
References
}

[1] A world bank Group Flashing Report Doing Business 2019 training for reform http://www.worldbank.org/content/dam/doingBusiness/media/Annual-Reports/English/DB2019-report_webversion.pdf (06.04.2019)

[2] Alturki, N. \& Braswell, S. (2010). Businesswomen in Saudi Arabia: Characteristics, Challenges, and Aspirations in a Regional ConTABtext. Jeddah, Saudi Arabia: Al-Sayedah Khadijah Bint Khuwailid Businesswomen Center and Riyadh, Saudi Arabia: Monitor Group.

[3] Armington, C. Acs, Z. [2002]. The Determinants of Regional Variation in New Firm Formation. Regional Studies, 36(1), 33-45 avilable at: https://econpapers.repec.org/article/tafregstd/v_3a36_3ay_3a2002_3ai_3a1_3ap_3a33-45.htm (20.2.2019.)

[4] Braicu, C., Bucea-Manea-Tonis, R., Bucea-Manea-Tonis, R., (2017). Knowledge management based on expert systems. Proceedings of the 30th International Business Information Management Association Conference, IBIMA 2017 - Vision 2020: Sustainable Economic development, Innovation Management, and Global Growth, URL: https://ibima.org/accepted-paper/knowledge-management-based-expert-systems/

[5] Drakulić, D., \& Budimčević, K. [2016]. Stanje i značaj daljeg razvoja ženskog preduzetništva. Anali Ekonomskog fakulteta u Subotici, (35), 3-12.

[6] Global Entrepreneurship Monitor GEM 2018 / 2019 Global Report, available at: https://www.gemconsortium.org/report (06.04.2019.)

[7] Ilić, M. [2017]. Osnove ekonomije, finansija i računovodstva. Visoka škola strukovnih studija za informacione tehnologije, ITS - Beograd.

[8] Jovanović, I., Arsić, M., \& Nikolić, Đ. [2018]. Lične predizetničke osobine i profitabilnost MSP u tranzicionoj ekonomiji. Serbian Journal of Management, 13(1), 89-104.

[9] Korosteleva, J., Stapien-Baig, P, (2019).Climbing the poverty ladder: the role of entrepreneurship and gender in alleviating poverty in transition economies. Entrepreneurship \& Regional Development, 1, 24, Routledge. https://doi.org/10.1080/08985626.2019.1640482

[10] Leković, B., Amidžić, R., \& Milićević, N. [2018]. Determinante internacionalizacije - preduzetnici u ranim fazama poslovanja sa područja Jugoistočne Evrope. Industrija, 46(4), 85-107.

[11] Maksimović, G., Otović, S., Demirović, D., \& Vermezović, Tatjana. [2016]. Pregled istraživanja ženskog agrarnog preduzetništva u Republici Srbiji. Ekonomika poljoprivrede, 63(1), 29-46

[12] Mandal, P, Vong, J. (eds.). [2017]. Entrepreneurship in Technology for ASEAN. Springer Singapore.

[13] Saxenian. A. [1999]. Silicon Valley's New Immigrant Entrepreneurs San Francisco. CA: Public Policy Institute of California. Available at: https://www.ppic.org/content/pubs/report/R_699ASR.pdf (20.2.2019.)

[14] Singh, H., Singh, R., \& Kota, B. H. [2018]. Posredna uloga uticaja, vizije i preduzetničkog konteksta. Serbian Journal of Management, 13(1), 185-195. 


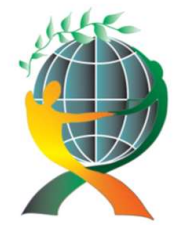

\author{
(online) $=$ ISSN $2285-3642$ \\ ISSN-L = $2285-3642$ \\ Journal of Economic Development, Environment and People \\ Volume 9, Issue 1, 2020 \\ URL: http://jedep.spiruharet.ro \\ e-mail: office jedep@spiruharet.ro
}

[15] Storey, D.J., Understanding the Small Business Sector (1994). University of Illinois at Urbana-Champaign's Academy for Entrepreneurial Leadership Historical Research Reference in Entrepreneurship. Available at SSRN: https://ssrn.com/abstract=1496214 (20.2.2019.)

[16] The Global Competitiveness Index 2017-2018 edition Slovenia http://www3.weforum.org/docs/GCR20172018/03CountryProfiles/Standalone2-pagerprofiles/WEF_GCI_2017_2018_Profile_Slovenia.pdf (06.04.2019.)

[17] Webb, J.W., Tihanyi, L., Ireland, R.D. \& Sirmon, D.G. (2009). You say illegal, I say legitimate: Entrepreneurship in the informal economy. Academy of Management Review, 34(3), 492-510.

[18] Global Entrepreneurship Monitor https://www.gemconsortium.org/ (06.04.2019.)

[19] World Economic Forum https:/www.weforum.org/events/world-economic-forum-on-the-middle-east-and-northafrica (01.04.2019).

[20] World Bank Ease of Doing Business https://data.worldbank.org/indicator/ic.bus.ease.xq (06.04.2019.)

[21] World Bank Starting a Business http://www.doingbusiness.org/en/data/exploretopics/starting-a-business (02.04.2019.)

[22] Statistical office of the Republic of Slovenia - SURS https://www.stat.si/statweb/en?AspxAutoDetectCookieSupport=1 (02.04.2019.)

[23] Croatian Bureau of Statistics https://www.dzs.hr/default_e.htm (02.04.2019.) 